\title{
Propagule pressure of an invasive crab overwhelms native biotic resistance
}

\author{
A. L. Hollebone, M. E. Hay* \\ School of Biology, Georgia Institute of Technology, 311 Ferst Drive, Atlanta, Georgia 30332-0230, USA
}

\begin{abstract}
Over the last decade, the porcelain crab Petrolisthes armatus invaded oyster reefs of Georgia, USA, at mean densities of up to 11000 adults $\mathrm{m}^{-2}$. Interactions affecting the invasion are undocumented. We tested the effects of native species richness and composition on invasibility by constructing isolated reef communities with 0,2 , or 4 of the most common native species, by seeding adult $P$. armatus into a subset of the 4 native species communities and by constructing communities with and without native, predatory mud crabs. At $4 \mathrm{wk}$, recruitment of $P$. armatus juveniles to oyster shells lacking native species was 2.75 times greater than to the 2 native species treatment and 3.75 times greater than to the 4 native species treatment. The biotic resistance produced by 2 species of native filter feeders may have occurred due to competition with, or predation on, the settling juveniles of the filter feeding invasive crab. Adding adult porcelain crabs to communities with 4 native species enhanced recruitment by a significant 3 -fold, and countered the effects of native biotic resistance. Differences in recruitment at Week 4 were lost by Weeks 8 and 12, when densities of recent recruits reached $\sim 17000$ to $34000 \mathrm{crabs} \mathrm{m}^{-2}$ across all treatments. Thus, native species richness slows initial invasion, but early colonists stimulate settlement by later ones and produce tremendous propagule pressure that overwhelms the effects of biotic resistance.
\end{abstract}

KEY WORDS: Exotic crab - Invasive species - Marine bioinvasion - Oyster reef - Recruitment · South Atlantic Bight

Resale or republication not permitted without written consent of the publisher

\section{INTRODUCTION}

Species invasions play an integral role in structuring biological communities (Vermeij 2001, 2005). Rates of natural invasions are modest, but human activities have exponentially increased the speed and extent of invasions (e.g. Cohen \& Carlton 1998, Mooney \& Cleland 2001). These elevated rates not only alter local community composition and function but also homogenize species across geographic scales (Olden et al. 2004) and exacerbate the global biodiversity crisis (Stachowicz et al. 2002). There is thus a critical need to understand what community traits affect susceptibility to invasion and what traits make some species so invasive.

Colonization of exotic species is affected by ecological resistance of the recipient community (Elton 1958). Numerous studies have focused on the biological factors limiting invasion success including competition
(Case \& Crawley 2000), predation or parasitism (Wolfe 2002, Torchin et al. 2003), and Elton's diversity-resistance hypothesis (1958), which suggests that community resistance will be proportional to native species richness (Tilman 1997, Kennedy et al. 2002). Recently, propagule pressure has been demonstrated to affect the ability of some forest and grassland species to invade established communities (Von Holle \& Simberloff 2005, Thomsen et al. 2006).

Compared to terrestrial systems, little is known about the mechanisms affecting an invader's densities and spread in marine habitats (but see Stachowicz et al. 1999, 2002, Dunstan \& Johnson 2004, DeRivera et al. 2005). Mesocosm studies of sessile invertebrate communities on 2-dimensional substrates demonstrated that biotic resistance can affect invasion success (e.g. Stachowicz et al. 1999), but it is unclear if such results will be predictive for mobile species in 3dimensional habitats under field conditions. Addition- 
ally, recruitment density (propagule pressure) could affect colonization success in marine communities (Ruiz \& Carlton 2003), but the potential effects of propagule pressure are poorly documented.

In this study, we assessed the effects of community composition (including native species richness) and the presence of adult conspecifics on recruitment rates of the invasive green porcelain crab Petrolisthes armatus. In 1994, this crab was first detected north of Cape Canaveral, Florida; within months, it had moved as far north as Winyah Bay, South Carolina (Knott et al. 2000). By 2004, mean densities in oyster reefs of Georgia and South Carolina comprised several thousand crabs $\mathrm{m}^{-2}$ (Hollebone \& Hay 2007, South Carolina Department of Natural Resources, www.dnr.sc.gov/marine/sertc/ $\mathrm{P} \% 20$ armatus $\% 20$ SOM.pdf). The crabs are filter feeders living among native, filter-feeding bivalves (potential competitors or larval predators) and mud crabs (potential predators), suggesting the potential for biotic resistance. The invasive crab recruits thousands of juveniles $\mathrm{m}^{-2}$ from the plankton during the warm months of the year (May to September, Hollebone \& Hay 2007), suggesting that propagule pressure could play a role in facilitating invasion. Although post-settlement population dynamics of juvenile and adult crabs have been documented (Hollebone \& Hay 2007), the supply-side, pre-settlement, and settlement-related mechanisms affecting invasion are unknown.

We addressed the following questions: (1) Does native species richness and composition produce biotic resistance to invasion at the horizontal (within trophic level, e.g. competing filter feeders) or vertical (consumers, e.g. predatory mud crabs) levels of diversity (Duffy 2002); (2) Does the presence of adult invasive crabs facilitate recruitment; and (3) What role does propagule pressure play in invasion success?

\section{MATERIALS AND METHODS}

The Eastern oyster Crossostrea virginica is a foundation species that creates the major hard-substrate community in estuarine ecosystems of the South Atlantic Bight, USA; this is a habitat on which many other species depend (Lenihan \& Peterson 1998). The green porcelain crab Petrolisthes armatus is a recent addition to these communities. During warmer months, mean densities of this crab can exceed 10000 individuals $\mathrm{m}^{-2}$, surpassing the combined densities of all common native crabs (mud crabs), by 2 - to 10 -fold (Hollebone \& Hay 2007). Common native macrofauna in oyster reefs include mussels Brachidontes exustus, oyster drills Urosalpinx cinerea, and mud crabs Panopeus herbstii and Eurypanopeus depressus. We focused on these organisms.
In the summer of 2004, we performed a constructed community study (Levine \& D'Antonio 1999) in which we manipulated the native species richness of spatially isolated oyster reef communities and monitored recruitment of juvenile Petrolisthes armatus (propagule pressure). Summer is the peak recruitment season for this crab (Hollebone \& Hay 2007). We established 12 replicated blocks of 4 community types including (1) a 0 native species treatment composed of only sunbleached oyster shells, (2) a 2 native species, filter-feeding community composed of live oysters and mussels at natural densities, (3) a 4 native species community composed of live oysters, mussels, mud crabs (a potential predator), and oyster drills (an oyster predator), and (4) the same 4 native species community as above seeded with adult $P$. armatus ( $>5.5 \mathrm{~mm}$ carapace width, $\mathrm{CW}$ ) at a density of $750 \mathrm{~m}^{-2}\left(\sim 55\right.$ to $75 \mathrm{~g}$ wet mass $\left.667 \mathrm{~cm}^{-2}\right)$. Each community was established in plastic baskets (29 cm long $\times 23 \mathrm{~cm}$ wide) with perforated sides (12 halfmoon-shaped holes, $6 \mathrm{~cm}$ long and $1.5 \mathrm{~cm}$ wide along the lengths; 4 holes plus 1 handhold, $10.5 \mathrm{~cm}$ long and $3 \mathrm{~cm}$ wide along the widths) and open tops allowing movement of organisms into and out of the baskets. We included 3 randomly distributed subsamplers within each basket (Fig. 1B); these could be removed to assess densities of newly settled crabs without disturbing the entire assemblage. Subsamplers were constructed from the lower $2 \mathrm{~cm}$ of a plastic deli container into which we glued a $16.0 \mathrm{~cm}$ tall cylinder of PVCcoated wire mesh (hexagonal shape, $4.0 \times 2.5 \mathrm{~cm}$ ).

Prior to experimentation, all visible organisms were manually removed from the surface of all oysters and mussels, and all mud crabs and porcelain crabs were measured $(\mathrm{CW})$ before placement into treatments. Experimental communities contained natural densities of each organism as determined by extensive monitoring of natural communities near our experimental plots during spring 2004 (Hollebone \& Hay 2007). Each basket contained $\sim 1.5 \mathrm{l}$ of live oysters or sun-bleached oyster shells as the underlying substrate and 10 mussels $\left(\sim 150 \mathrm{~m}^{-2}\right), 15$ oyster drills $\left(\sim 225 \mathrm{~m}^{-2}\right)$, and 3 large $\left(>18 \mathrm{~mm} \mathrm{CW} ; 45 \mathrm{~m}^{-2}\right.$ ) and 5 small (10 to $18 \mathrm{~mm} \mathrm{CW}$; $75 \mathrm{~m}^{-2}$ ) mud crabs Panopeus herbstii according to the assigned treatment.

Treatments were spatially blocked and placed on 3 isolated mud flats near Skidaway Island, Georgia (Fig. 1A, Sites 1 to 3). Mud flats were used because we wanted to assess recruitment from the plankton and needed to preclude migration of post-settlement crabs from nearby oyster reefs. All blocks were established $\geq 20 \mathrm{~m}$ from the edge of the nearest oyster reef or from another experimental block, and each basket was $5 \mathrm{~m}$ from its nearest neighbor. Treatment types were randomly assigned to a position within each blocked array. The baskets were anchored with rebar stakes 

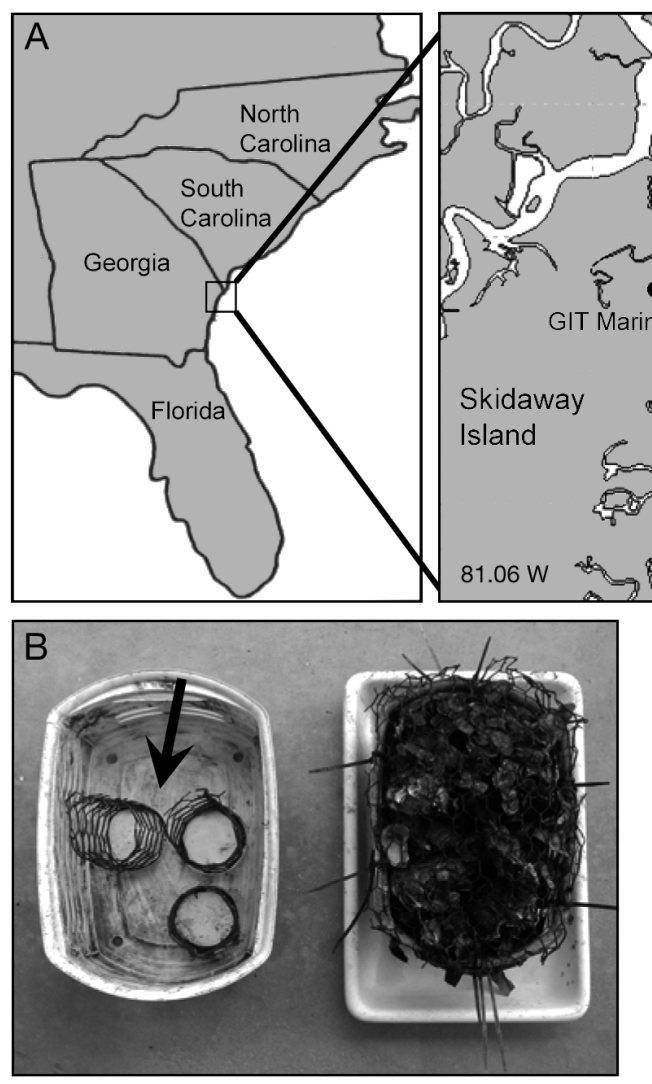

Fig. 1. (A) Location of study sites (Sites 1, 2, 3) near Skidaway Island, Georgia, USA. (B) Plastic baskets with and without oysters. Subsampling devices (arrowed) are shown in basket on left before filling with oyster substrate

had 1 to 3 adults subsampler ${ }^{-1}$ at Week 4 ; it is unlikely that these were colonizing adults because a quick assessment at Week 2 indicated only 1 adultsized crab among 18 unseeded subsamplers).

Densities of recruiting Petrolisthes armatus were scaled to $1 \mathrm{~m}^{-2}$. Data were square root-transformed to meet the requirements of normality (RyanJoiner $W$-test, $\mathrm{p}>0.05$, one violation remained following transformation with the 2 species treatment at $12 \mathrm{wk}$ ) and equality of variances (F-test, p > 0.05). Effects of time, treatment, and the interaction were assessed via a 2way ANOVA. We did not use a repeated-measures ANOVA because we sampled different baskets during alternating sampling periods and we only took 1 small subsample from each basket leaving most of each basket undisturbed and unanalyzed. We further analyzed the short-term effect of community composition on differential recruitment of $P$. armatus at Week 4 using a 1-way ANOVA and TukeyKramer post hoc test $(\mathrm{p} \leq 0.05)$ because

and oriented lengthwise to the incoming tide along one transect parallel to the shore $(0.3$ to $0.5 \mathrm{~m}$ above mean lower low water). Baskets were covered with the same PVC-coated wire mesh used to construct subsamplers; this prevented oyster wash-out by physical disturbance. This mesh may have limited access of some larger consumers (e.g. adult fishes, blue crabs) but would not impede movement of smaller consumers (e.g. mud crabs, blennies) or recruitment by Petrolisthes armatus. Porcelain crab densities in these experimental communities were similar to those on natural reefs (Hollebone \& Hay 2007).

Recruitment of Petrolisthes armatus was monitored at Weeks 4, 8, and 12. The length of each low tide allowed for processing only 6 of the original 12 blocks each sampling period. At the next sampling period, we sampled baskets from the 6 blocks that had not been processed previously. We removed one randomly selected subsampler from each community treatment, counted all crabs retained on a $500 \mu \mathrm{m}$ sieve, and returned all material and organisms to the subsampler, which was placed back into the basket. Recruited versus seeded $P$. armatus were defined by size: $\geq 5.5 \mathrm{~mm}$ CW (seeded adults) or $<5.5 \mathrm{~mm} \mathrm{CW}$ (recruit). This designation underestimated recruitment because a few crabs grew to the defined adult size range within the first 4 wk (i.e. some replicates initially without adults this was the only sampling period when adult crabs were still absent or rare in unseeded treatments.

During the summer of 2005, we again assessed the effects of adult Petrolisthes armatus on juvenile recruitment as well as the potential for predation by native mud crabs to produce the biotic resistance we noted in 2004. Experimental oyster communities consisted of: (1) live, defaunated oysters; (2) oysters seeded with adult porcelain crabs $(\geq 5.5 \mathrm{~mm} \mathrm{CW}, 40$ crabs basket $^{-1}$ or $\sim 1200$ crabs $^{-2}$ ); or (3) live oysters with mud crabs ( 2 crabs $>18 \mathrm{~mm} \mathrm{CW}$ and 3 crabs 10 to $18 \mathrm{~mm} \mathrm{CW}$ ) and adult porcelain crabs at the above density. We increased the density of $P$. armatus in this follow-up study (1200 versus $750 \mathrm{crabs}^{-2}$ ) because mean densities of the crabs in the field commonly range from 1000 to $11000 \mathrm{~m}^{-2}$ during the summer months (Hollebone \& Hay 2007). We did not try to mimic the upper levels of adult invasive crab densities because of the difficulty of capturing the fast-moving crabs from among the sharp edges of the oysters, and because of the time required to capture and measure thousands of crabs. To minimize sorting effort, the baskets used in the initial study were divided in half by securing $0.64 \mathrm{~cm}$ plastic mesh across the inner width of the basket. Half of each basket was then filled with defaunated live oyster substrate and treatmentspecific crabs; the other half remained empty. 
The 3 treatments were randomly assigned a position in 10 linear blocked arrays over 2 mud flats (Sites 1 and 2 in Fig. 1; Site 3 was not used because of physical disturbances). Placement was as described previously. After $4 \mathrm{wk}$, baskets were returned to the laboratory, where porcelain crabs were counted and identified as recruits $(<5.5 \mathrm{~mm} \mathrm{CW})$ or seeded adults $(\geq 5.5 \mathrm{~mm} \mathrm{CW})$. Data were scaled to $1 \mathrm{~m}^{2}$, tested for normality (Ryan Joiner $W$-test, p > 0.05) and equality of variances (F-test, p > 0.05), and analyzed with a 1-way ANOVA and Tukey-Kramer post hoc test.

\section{RESULTS}

Densities of juvenile Petrolisthes armatus rose from zero to $\sim 17000$ to 34000 crabs m$^{-2}$ in 12 wk (Fig. 2); these densities are conservative because we defined recruits as being $<5.5 \mathrm{~mm}$ carapace width, and newly settled crabs can grow to this adult size within $4 \mathrm{wk}$. Densities for all treatments were 2000 to 8000 newly settled crabs $\mathrm{m}^{-2}$ after only $4 \mathrm{wk}$. When the data were analyzed across all times and treatments, density of juvenile $P$. armatus increased over time ( $\mathrm{df}=2, F=$ 46.7, p < 0.001), but there was no significant effect of treatment $(\mathrm{df}=3, F=1.0, \mathrm{p}=0.397$ ) or treatment $\times$ time interaction ( $\mathrm{df}=6, F=1.8, \mathrm{p}=0.119$ ). However, some of our original treatments involved the absence of adult $P$. armatus, and recruitment was so rapid that these treatments were compromised after only a few weeks. We were concerned that these experimental communities may have initially differed in their attraction to recruits but that this effect was quickly overwhelmed. To assess this, we evaluated our Week 4 data separately. At this time, recruitment to sunbleached oyster shells (0 native species) significantly exceeded recruitment to the treatments with either 2

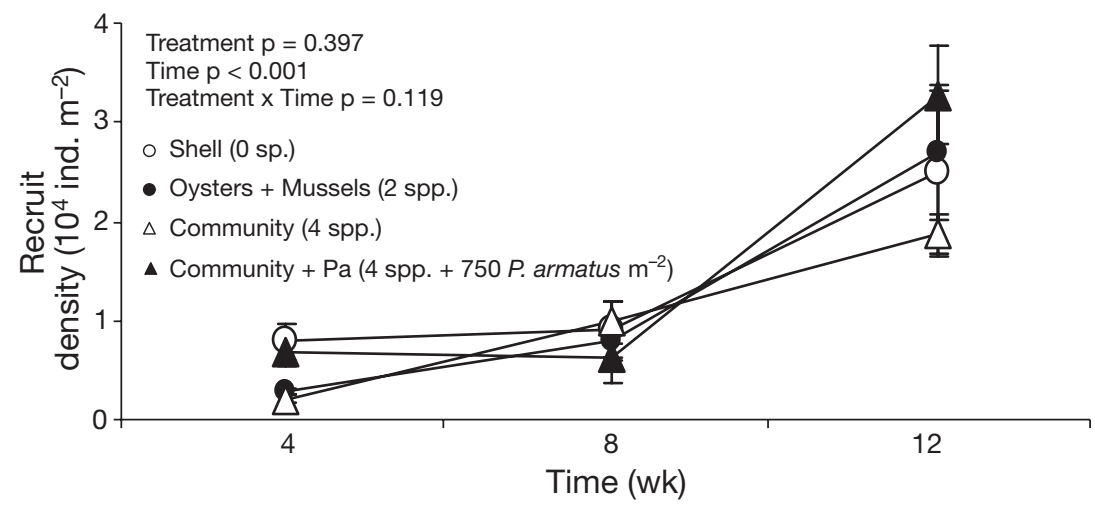

Fig. 2. Petrolisthes armatus. 2004 field experiment. Density (mean \pm SE) of recruits over $12 \mathrm{wk}$ in constructed oyster reefs that differed in species composition. $\mathrm{p}$-values from repeated-measures ANOVA following transformation of data

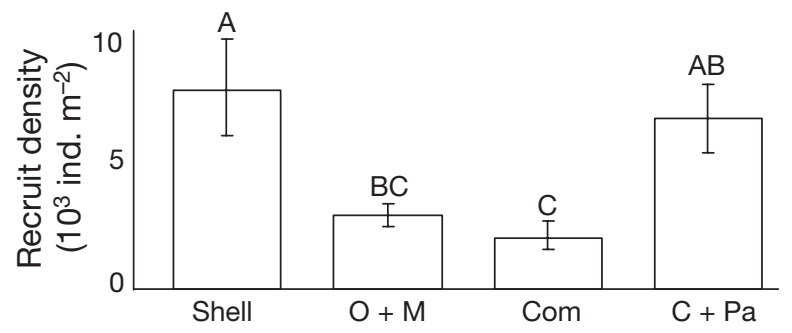

Fig. 3. Petrolisthes armatus. 2004 field experiment. Density (mean $\pm \mathrm{SE}$ ) at Week 4 of recruits in constructed oyster reefs that differed in species composition. Different letters indicate statistically significant, among-treatment differences (ANOVA, Tukey-Kramer, $\mathrm{p} \leq 0.05$ ). Shell $=0$ spp.; $\mathrm{O}+\mathrm{M}=$ oysters and mussels (2 spp.); Com = community (4 spp.); $\mathrm{C}+\mathrm{Pa}=$ community +750 P. armatus $\mathrm{m}^{-2}$

or 4 native species alone (Fig. 3, ANOVA, TukeyKramer $\mathrm{p} \leq 0.05$ ). However, when the treatment with 4 native species was seeded with adult porcelain crabs, recruitment from the plankton increased significantly (compared with the unseeded 4 native species treatment) and attained levels equivalent to those seen in the 0 native species treatment (Fig. 3). Communities composed of 2 native filter feeders versus those with the 2 native filter feeders plus 2 native consumers (mud crabs and oyster drills) did not differ in the rates at which they attracted juvenile P. armatus (Fig. 3)

Our 2005 study confirmed that adult Petrolisthes armatus significantly enhanced recruitment of juvenile conspecifics; in contrast, native mud crabs, a potential predator, had no effect on recruitment (Fig. 4). After 4 wk, $\sim 10000$ crabs $\mathrm{m}^{-2}$ had recruited to the treatment without adult porcelain crabs, but $\sim 17000 \mathrm{crabs} \mathrm{m}^{-2}$ had recruited to the treatment with adult porcelain crabs; thus, overall recruitment was again rapid.

\section{DISCUSSION}

Biotic invasions homogenize biota and contribute to the loss of global biodiversity (Wilcove et al. 1998), thus necessitating a better understanding of the community and species traits determining invasion success (Stachowicz et al. 2002). Most experimental assessments of invasions have focused on small-scale manipulations (e.g. native species richness, nutrient regimes, flooding episodes) in terrestrial systems (e.g. Tilman 1997, Naeem et al. 2000, Hector et al. 2001). Similar studies in marine systems have focused primarily on the effects of native species richness and on sessile invertebrates 


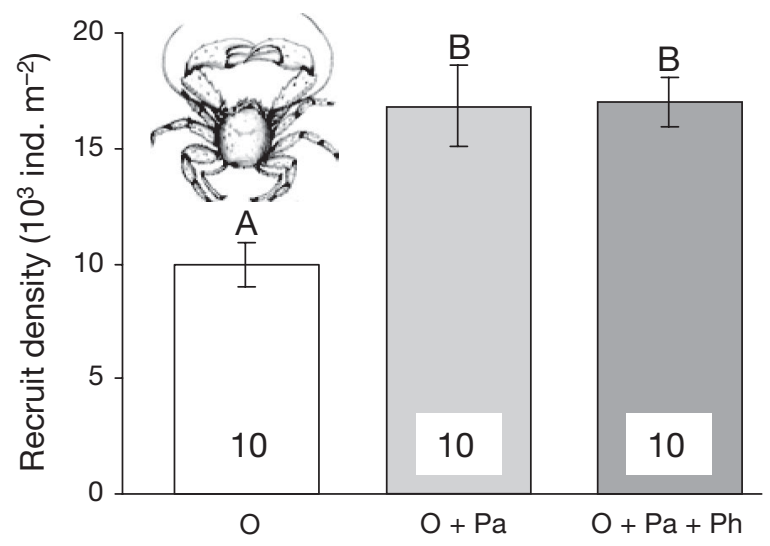

Fig. 4. Petrolisthes armatus. 2005 field experiment. Density (mean $\pm \mathrm{SE}$ ) of recruits in 3 constructed community types after 4 wk. $\mathrm{O}=$ live oysters; $\mathrm{O}+\mathrm{Pa}=$ live oysters with 1200 porcelain crabs $\mathrm{m}^{-2} ; \mathrm{O}+\mathrm{Pa}+\mathrm{Ph}=$ live oysters with 1200 porcelain crabs ${ }^{-2}$; 60 large ( $\left.>18 \mathrm{~mm} \mathrm{CW}\right)$ and 90 small (10 to $18 \mathrm{~mm} \mathrm{CW}$ ) mud crabs $\mathrm{m}^{-2}$. Different letters indicate significant, among-treatment differences (ANOVA, TukeyKramer, $\mathrm{p} \leq 0.05$ )

that are easily manipulated (e.g. Stachowicz et al. 1999, 2002, but see effect of predation as biotic resistance in DeRivera et al. 2005). Our investigation assessed the invasion of a highly mobile crustacean in a field setting where colonization was limited to recruitment from the plankton.

After $4 \mathrm{wk}$ in the field, both the absence of native species (shell structure only) and the presence of adult conspecifics significantly enhanced recruitment of Petrolisthes armatus compared with the treatment containing 4 native species. Shell structure alone also attracted more porcelain crab recruits than the treatment with 2 native species. Adding native consumers to the community composed of only the 2 filter feeders did not diminish $P$. armatus recruitment (Fig. 3). This suggests that biotic resistance may have been generated by competition with filter feeders or by consumption of settling juvenile crabs by filter feeders. In addition, the presence of predatory mud crabs in our 2005 experiment did not suppress $P$. armatus recruitment, again indicating that native mud crabs do not suppress juvenile invasive crabs. Adult oysters can consume $~ 80$ to $90 \%$ of native crustacean larvae within the range of 0.5 to $1.5 \mathrm{~mm}$ in body length (Tamburri \& ZimmerFaust 1996). P. armatus megalopa are within this size range, suggesting that suppression by oysters could be due to direct consumption.

The patterns shown in Figs. $2 \& 4$ are consistent with native species generating biotic resistance to invasion but with seeded or quickly recruiting Petrolisthes armatus facilitating recruitment of later-arriving porcelain crabs. Previous colonizers thus enhance propagule pressure and overwhelm initial biotic resistance of the native community. The eventual colonization of all treatments by $P$. armatus may have stimulated settlement by Weeks 8 and 12, when we no longer saw among-treatment differences in densities of recent recruits (all treatments had between $\sim 17000$ and 34000 recently settled crabs $\mathrm{m}^{-2}$ ).

The Pacific congener Petrolisthes cinctipes also preferentially recruits to adult conspecifics; benefits of this behavior include habitat cueing, reduced predation, and access to mates (Jensen \& Armstrong 1991, Donahue 2004). Similar benefits may exist for $P$. armatus invading oyster reefs of the South Atlantic Bight.

Studies in terrestrial systems have recently suggested that the swamping of ecological communities by propagules of invasive species may be a common, yet relatively unexplored phenomenon. Propagule pressure explains variation in establishment success for a wide-range of organisms including insects, fishes, birds, and mammals (reviewed in Lockwood et al. 2005), although many of these introductions were staged by researchers. Von Holle \& Simberloff (2005) and Thomsen et al. (2006) used controlled field studies to demonstrate that propagule pressure alone or in conjunction with abiotic factors can lead to successful invasions in forests and grasslands.

In field studies during both 2004 and 2005, 2000 to $17000 \mathrm{crabs} \mathrm{m}^{-2}$ recruited to our experimental baskets after only 4 wk. These densities could be artificially high and not representative of natural oyster reefs if our spatially isolated baskets attracted large numbers of recruits in mud flats otherwise lacking in adequate settlement sites, or if the baskets themselves attracted recruits. We did not rigorously test these hypotheses, but high recruit densities also occurred in natural oyster reefs near our study sites. Seasonal monitoring across 2 large estuaries in Georgia demonstrated that densities within oyster reefs rapidly increased by hundreds to thousands of crabs $\mathrm{m}^{-2}$ in the warmer months (Hollebone \& Hay 2007).

Although native species create biotic resistance to invasions in some communities (e.g. Tilman 1997, Stachowicz et al. 1999, Kennedy et al. 2002, Parker et al. 2006), the tremendous rates of recruitment that we documented here (Figs. 2 \& 4) and on natural oyster reefs (Hollebone \& Hay 2007) suggest that Petrolisthes armatus propagule pressure coupled with conspecific cueing overwhelmed biotic resistance to invasion. The high propagule pressure results from adult densities of $P$. armatus in its new range being 10 to 37 times greater than the highest densities ever reported in its presumed historic range, and from the reproductive output of these dense populations of $P$. armatus exceeding that of populations in the native range by at least 1 order of magnitude (Hollebone \& Hay 2007). Thus, unless physical or biological processes in the invaded 
range shift in ways that diminish adult densities, fecundity, or both, $P$. armatus will likely continue to colonize and prosper in its new, more northern range.

Acknowledgements. We thank M. Ferner, P. Munguia, and D. L. Smee for field assistance, K. Hollebone for the artwork, and M. Miller, T. Snell, J. T. Streelman, M. Weissburg, and 2 anonymous reviewers for comments on the manuscript. Support was provided by an EPA STAR Graduate Fellowship (U915531-01-0) and a NOAA NERRS Graduate Research Fellowship (NA03NOS4200063) to A.L.H. with additional funding from the Georgia Institute of Technology and the Harry and Linda Teasley Endowment. This study was part of a PhD dissertation in the School of Biology at the Georgia Institute of Technology.

\section{LITERATURE CITED}

Case CM, Crawley MJ (2000) Effect of interspecific competition and herbivory on the recruitment of an invasive alien plant: Conyza sumatrensis. Biol Invasions 2:103-110

Cohen AN, Carlton JT (1998) Accelerating invasion rate in a highly invaded estuary. Science 279:555-557

DeRivera CE, Ruiz GM, Hines AH, Jivoff P (2005) Biotic resistance to invasion: native predator limits abundance and distribution of an introduced crab. Ecology 86: 3364-3376

Donahue MJ (2004) Size-dependent competition in a gregarious porcelain crab Petrolisthes cinctipes (Anomura: Porcellanidae). Mar Ecol Prog Ser 267:219-231

Duffy JE (2002) Biodiversity and ecosystem function: the consumer connection. Oikos 99:201-219

Dunstan PK, Johnson CR (2004) Invasion rates increase with species richness in a marine epibenthic community by two mechanisms. Oecologia 138:285-292

Elton CS (1958) The ecology of invasions by animals and plants, Methuen, London

Hector A, Dobson K, Minns A, Bazeley-White E, Lawton J (2001) Community diversity and invasion resistance: an experimental test in a grassland ecosystem and a review of comparable studies. Ecol Res 16:819-831

Hollebone AL, Hay ME (2007) Population dynamics of the non-native crab Petrolisthes armatus invading the South Atlantic Bight at densities of thousands $\mathrm{m}^{-2}$. Mar Ecol Prog Ser 336:211-223

Jensen GC, Armstrong DA (1991) Intertidal zonation among congeners: factors regulating distribution of porcelain crabs Petrolisthes spp. (Anomura: Porcellanidae). Mar Ecol Prog Ser 73:47-60

Kennedy TA, Naeem S, Howe KM, Knops JM, Tilman D, Reich P (2002) Biodiversity as a barrier to ecological invasion. Nature 417:636-638

Knott D, Boyko C, Harvey A (2000) Introduction of the green porcelain crab, Petrolisthes armatus (Gibbes, 1850), into the South Atlantic Bight. In: Pederson J (ed) Marine bioinvasions: Proceedings of the First National Conference,

Editorial responsibility: Otto Kinne (Editor-in-Chief) Oldendorf/Luhe, Germany
January 24-27, 1999. MIT Sea Grant College Program, Cambridge, MA

Lenihan HS, Peterson CH (1998) How habitat degradation through fishery disturbance enhances impacts of hypoxia on oyster reefs. Ecol Appl 8:128-140

Levine JM, D'Antonio CM (1999) Elton revisited: a review of evidence linking diversity and invasibility. Oikos 87:15-26

Lockwood JL, Cassey P, Blackburn T (2005) The role of propagule pressure in explaining species invasions. Trends Ecol Evol 20:223-228

Mooney HA, Cleland EE (2001) The evolutionary impact of invasive species. Proc Natl Acad Sci 98:5446-5451

Naeem S, Knops JMH, Tilman D, Howe KM, Kennedy TA, Gale S (2000) Plant diversity increasing resistance to invasion in the absence of covarying extrinsic factors. Oikos 91:97-108

Olden JD, Poff NL, Douglas MR, Douglas ME, Fausch KD (2004) Ecological and evolutionary consequences of biotic homogenization. Trends Ecol Evol 19:18-24

Parker JD, Burkepile DE, Hay ME (2006) Opposing effects of native and exotic herbivores on plant invasives. Science 311:1459-1461

Ruiz GM, Carlton JT (2003) Invasion vectors: a conceptual framework for management. In: Ruiz GM, Carlton JT (eds) Invasion vectors. Island Press, Washington, DC, p 459-504

Stachowicz JJ, Whitlach RB, Osman RW (1999) Species diversity and invasion resistance in a marine ecosystem. Science 286:1577-1579

Stachowicz JJ, Fried H, Osman RW, Whitlach RB (2002) Biodiversity, invasion resistance, and marine ecosystem function: reconciling pattern and process. Ecology 83:2575-2590

Tamburri MN, Zimmer-Faust RK (1996) Suspension feeding: basic mechanisms controlling recognition and ingestion of larvae. Limnol Oceanogr 41:1188-1197

Thomsen MA, D'Antonio CM, Suttle KB, Sousa WP (2006) Ecological resistance, seed density and their interactions determine patterns of invasion in a California coastal grassland. Ecol Lett 9:160-170

Tilman D (1997) Community invasibility, recruitment limitation, and grassland biodiversity. Ecology 78:81-92

Torchin ME, Lafferty KD, Dobson AP, McKenzie VJ, Kuris AM (2003) Introduced species and their missing parasites. Nature 421:628-630

Vermeij GJ (2001) Community assembly in the sea: geologic history of the living shore biota. In: Bertness MD, Gaines SD, Hay ME (eds) Marine community ecology. Sinauer, Sunderland, MA

Vermeij GJ (2005) Invasion as expectation: a historical fact of life. In: Sax DF, Stachowicz JJ, Gaines SD (eds) Species invasions: insights into ecology, evolution, and biogeography. Sinauer, Sunderland, MA

Von Holle B, Simberloff D (2005) Ecological resistance to biological invasion overwhelmed by propagule pressure. Ecology 86:3212-3218

Wilcove DS, Rothstein D, Dubow J, Phillips A, Losos E (1998) Quantifying threats to imperiled species in the United States. BioScience 48:607-615

Wolfe LM (2002) Why alien invaders succeed: support for the escape-from-enemy hypothesis. Am Nat 160:705-711

Submitted: June 19, 2006; Accepted: November 22, 2006 Proofs received from author(s): July 4, 2007 